\title{
An $\alpha 5 \beta 1$ - like integrin receptor mediates the binding of less pathogenic Candida species to fibronectin
}

\author{
G. SANTONI*, P. BIRARELLI*, L. JIN HONG $\dagger$, A. GAMERO $\dagger$, J. Y. DJEU $\dagger$ and M. PICCOLI* \\ Chair of General Pathology, University of Camerino, Camerino, Italy, "Department of Experimental Medicine, \\ University of Rome "La Sapienza", Rome, Italy and + Moffitt Cancer Center, University of South Florida, \\ Tampa, FL, USA
}

\begin{abstract}
Summary. The present study was undertaken to investigate whether less pathogenic Candida species (C. tropicalis, C. stellatoidea, $C$. krusei and C. glabrata) express a fibronectin receptor $(\mathrm{FNr})$ antigenically related to $\alpha 5 \beta 1$ integrin, which mediates their binding to fibronectin (FN). By flow cytometric analysis, a monoclonal antibody (MAb) directed against human $\alpha 5$ integrin subunit (clone SAM-1) and two different antisera to $\mathrm{FNr}$ positively stained C. tropicalis, $C$. stellatoidea and $C$. glabrata, with the greatest expression observed for $C$. tropicalis. No or only marginal immunoreactivity was found on C. krusei. C. tropicalis, C. stellatoidea, $C$. glabrata, but not $C$. krusei yeasts specifically adhered to $\mathrm{FN}$; higher levels of adhesion were found for $C$. tropicalis and C. stellatoidea with respect to C. glabrata. Less pathogenic Candida spp. bound to the Arg-Gly-Asp (RGD) containing 120-kDa fragment of FN and adhesion to intact FN was markedly inhibited by Gly-Arg-Gly-Asp-Ser-Pro (GRGDSP), but not by Gly-Arg-Gly-Glu-Ser-Pro (GRGESP) peptides. In addition, anti- $\alpha 5$ SAM-1 MAb and both anti-FNr antisera strongly blocked binding of less pathogenic Candida spp. to FN. Overall, these results indicate that less pathogenic Candida spp., including $C$. tropicalis, $C$. stellatoidea and $C$.glabrata, express a receptor antigenically related to $\alpha 5 \beta 1$ integrin which mediates their adhesion to $\mathrm{FN}$.
\end{abstract}

\section{Introduction}

Candida spp. have emerged as important causes of nosocomial infections. ${ }^{1-5}$ The rise in life-threatening opportunist mycoses reflects the increase in high-risk immunocompromised hosts, including immunodeficiency virus-infected individuals, ${ }^{6-8}$ patients undergoing kidney or bone marrow transplantation, ${ }^{9-11}$ or those with cancer. ${ }^{12-15}$ Among opportunist mycoses, Candida spp. are now the fourth most commonly isolated organisms in blood cultures. C. albicans accounts for $60-80 \%$ of isolates, whereas less pathogenic Candida spp. including $C$. stellatoidea, $C$. tropicalis, C. krusei and C. glabrata account for the remaining clinical specimens. ${ }^{5,10.16}$ The importance of non-albicans Candida spp. is due to their increasing frequency, the emerging tolerance or resistance to antimycotic agents, as well as the higher mortality associated with their infections. ${ }^{11.17-19}$

Candida spp. show a wide range of infectious capabilities. Thus, the infections can vary from superficial mucosal lesions to multiple visceral organ in- volvement. The gravest complication of candida infections is disseminated disease resulting in clinical entities such as endocarditis, pyelonephritis, endophthalmitis, osteomyelitis or chronic mucocutaneous infections. ${ }^{20-25}$

The pathogenesis of these lesions is not completely understood, but is known to involve adherence to endothelial and epithelial cells as well as to extracellular matrix (ECM) components. ${ }^{16,26-35}$ Adherence to ECM represents a crucial step in the development of candidosis and is considered a significant virulence factor for these fungi, as the ability of Candida spp. to bind ECM proteins correlates with their relative pathogenicity. ${ }^{36-38}$

Among the molecules involved in cell adhesion to ECM proteins, integrins are a supergene family of highly conserved receptors that mediate cell-matrix and cell-cell interactions in embryogenesis, haemostasis, wound healing, tumour invasion, immune responses, inflammation and infectious diseases. ${ }^{39,40}$ Integrins are a gene family of $15 \alpha$ chains and $8 \beta$ chains expressed on a wide variety of mammalian cells, including epithelial and endothelial cells and leucocytes. Integrin receptors are heterodimers composed 
of non-covalently linked $\alpha$ and $\beta$ subunits. Both $\alpha$ and $\beta$ chains have cytoplasmic tails that mediate intracellular signalling via interaction with cytoskeleton components. At least eight different integrin subfamilies have been characterised on the basis of the association of distinct $\alpha$ chains with common or related $\beta$ subunits. In the $\beta 1$ family, $\alpha 5 \beta 1$ is the first integrin identified as the fibronectin $(\mathrm{FN})$ receptor $(\mathrm{FNr})$ and binds only FN recognising the Arg-Gly-Asp (RGD) sequence in the central region of the molecule. ${ }^{41}$

Candida spp. adhere to $\mathrm{FN}^{30,31,35,42,43}$ but the mechanisms of interaction with $\mathrm{FN}$ are poorly defined. We have recently demonstrated an FNr in C. albicans antigenically related to the $\alpha 5 \beta 1$ integrin that is involved in the adherence of both yeast and germ-tube phases to $\mathrm{FN}^{.{ }^{43}}$ An FNr belonging to the $\beta 1$ integrin subfamily has been identified also on $C$. albicans by Klotz et al. ${ }^{42}$ binding to FN was inhibited by RGDcontaining peptides whereas carbohydrates including D-mannose did not affect adhesion.

The present study was undertaken to investigate the expression of the $\alpha 5 \beta 1$ integrin and its functional role in mediating the adhesive interaction of FN with less pathogenic Candida spp.

A better understanding of the mechanisms by which Candida spp. adhere to ECM proteins may be useful in the development of new therapeutic strategies to prevent disseminated infections.

\section{Materials and methods}

\section{Candida spp.}

C. tropicalis (two clinical isolates), C. stellatoidea (two isolates), C. glabrata (two isolates) and C. krusei (two isolates) were identified by the API $20 \mathrm{C}$ system in the Microbiology and Immunology Laboratory of the University of South Florida, Tampa, FL, USA. Yeasts were cultured in Sabouraud's Dextrose Agar (Unipath) and frozen at $-80^{\circ} \mathrm{C}$ in small volumes in Saboraud broth containing glycerol $5 \%$ until use. For assays, a loopful of yeasts was placed in $50 \mathrm{ml}$ of Saboraud dextrose broth and incubated with shaking at $26^{\circ} \mathrm{C}$ for $20 \mathrm{~h}$. Yeast cells were washed twice with cold PBS by centrifugation at $3000 \mathrm{rpm}$ for $10 \mathrm{~min}$, pelleted and examined microscopically to exclude the presence of germ-tube or pseudohyphal phases. All isolates were tested for their ability to adhere to FN and found to be equivalent. Therefore, one isolate of each Candida spp. was used in all the experiments.

\section{Antibodies}

The following mouse monoclonal antibodies (MAbs) were used: anti- $\alpha 5$, clone P1D6 (IgG3) was purchased from Telios Pharmaceuticals Inc. (San Diego, CA, USA); anti- $\alpha 5$, clone SAM-1 (IgG2b) from AMAC Inc. (Westbrook, ME, USA); anti- $\beta 1$, clone 4B4 (IgG1) and clone A1A5 (IgG2b) were obtained from Coulter (Hialeah, FL, USA) and as a gift from Dr M. Hemler (Dana-Farber Cancer Institute, Boston, MA, USA), respectively. A rabbit polyclonal antibody raised against affinity-purified human placenta FNr (R $\alpha \mathrm{FNr})$ was purchased from Calbiochem Corp. (La Jolla, CA, USA). A goat polyclonal antibody reactive with the $\beta 1$ subunit, raised against affinity-purified human placenta $\mathrm{FNr}$ $(\mathrm{G} \alpha \mathrm{FNr}$ ) was provided by Dr G. Tarone (University of Turin, Turin, Italy). ${ }^{44} \mathrm{~A}$ MAb to a cell surface glucomannoprotein constituent of $C$. albicans (clone AF1) was kindly provided by Dr A. Cassone (Istituto Superiore di Sanita, Rome, Italy). ${ }^{45} \mathrm{~F}\left(\mathrm{ab}^{\prime}\right)_{2}$ fragment and Ig fraction of goat polyclonal antibody against human FN were purchased from Sigma and Cappel Laboratories (Cooper Biomedical Inc., Malvern, PA, USA). Purified FITC-conjugated goat $F\left(a b^{\prime}\right)_{2}$ fragment anti-mouse (GaM), and anti-rabbit $\mathrm{Ig}(\mathrm{GaR})$, rabbit $\mathrm{F}\left(\mathrm{ab}^{\prime}\right)_{2}$ fragment anti-goat $\operatorname{Ig}(\mathrm{RaG})$ were purchased from Cappel Laboratories.

\section{Adhesive proteins and peptides}

Human plasma FN was purchased from Gibco Laboratories (Grand Island, NY, USA). The 120-kDa FN proteolytic fragment was obtained from Calbiochem Corp. Substrate preparations were >95\% pure as checked by SDS-PAGE. The GRGDSP and GRGESP peptides were purchased from Telios Pharmaceuticals Inc.

\section{Immunofluorescence and flow cytometry}

Aliquots of $10^{6}$ yeast cells were incubated with a saturating dose of the first antibody for $30 \mathrm{~min}$ at $4^{\circ} \mathrm{C}$ and then washed twice with cold PBS. Cells were incubated with the FITC-conjugated second antibody for $30 \mathrm{~min}$ at $4^{\circ} \mathrm{C}$, washed twice and resuspended in PBS. Second-step reagents as well as irrelevant isotype-matched MAb plus GaM were used as negative controls. Cells were analysed for relative fluorescence intensity and the percentage of positively stained cells was determined over 10000 events on a FACScan cytofluorimeter (Becton Dickinson, Mountain View, CA, USA). Fluorescence intensity is expressed in arbitrary units on a logarithmic scale. The results are presented both as mean fluorescence intensity (MFI) and percentage of positive cells. Positive yeast cells exhibited an increase in fluorescence intensity above autofluorescence, and the signal from negative cells was not greater than that of the autofluorescence control.

\section{Labelling of Candida spp.}

Yeast cells $\left(10^{8}\right)$ were labelled with $25 \mu \mathrm{Ci}$ of ${ }^{3} \mathrm{H}$ glucose (Glucose D- $\left(5,6-{ }^{3} \mathrm{H}\right)$, specific activity $66.6 \mathrm{Ci} / \mathrm{mmol}$; Dupont Comp. Biotechnology, Wilmington, DE, USA) in $2.5 \mathrm{ml}$ of PBS supplemented with $0.5 \mathrm{mM} \mathrm{CaCl}_{2}$ and $\mathrm{MgCl}_{2}$ for $3 \mathrm{~h}$ at room temperature as described previously. ${ }^{46}$ After labelling, 
yeast cells were washed three times in cold PBS to remove free isotope, counted and adjusted to a concentration of $5 \times 10^{6} / \mathrm{ml}$ in PBS supplemented with $0.5 \mathrm{mM} \mathrm{CaCl}_{2}$ and $\mathrm{MgCl}_{2}$.

\section{Adhesion assay}

Stock preparations of human plasma FN and its proteolytic $120-\mathrm{kDa}$ fragment were diluted in PBS, $\mathrm{pH} 7 \cdot 4$, at a concentration of $25 \mu \mathrm{g} / \mathrm{ml}$, which has been determined previously to be optimal (data not shown). Protein solution $(100 \mu \mathrm{l})$ was distributed in 96-well tissue culture flat-bottomed plates (Costar, Cambridge, MA, USA). After overnight incubation at $4^{\circ} \mathrm{C}$, the coated plates were washed three times with PBS to remove unbound protein. Labelled yeast cells $\left(5 \times 10^{5}\right)$ of each representative isolate of Candida spp. were allowed to adhere to the protein-coated surface for $30 \mathrm{~min}$ at $37^{\circ} \mathrm{C}$ in $\mathrm{CO}_{2} 5 \%$. Optimal cell concentrations for all Candida spp. were determined by dose-response experiments (data not shown). Adhesion was verified microscopically; yeast phase was maintained throughout the adhesion assay and agglutination was not observed.

Unattached cells were removed by extensive washing with warm PBS and adherent cells were harvested by adding $100 \mu \mathrm{l}$ of Trypsin-EDTA (Flow Laboratories) solubilised in $0.5 \mathrm{M} \mathrm{NaOH}$ for $10 \mathrm{~min}$ at $37^{\circ} \mathrm{C}$. Bound $\mathrm{cpm}$ as well as cpm from non-adherent cells plus washes were quantitated in a Wallac Pharmacia $1410, \beta$ scintillation counter. Quadruplicate wells were assayed for each sample.

To rule out the contribution of yeast cell binding to plastics in the adhesion to $\mathrm{FN}$, assays were always performed in the presence of saturating doses of anti-FN antibodies, which completely abolished cell binding to FN, while not affecting attachment to the plastic surface as described previously. ${ }^{43}$

Total adhesion was calculated according to the following formula: $\mathrm{cpm}$ (adherent cells)/total $\mathrm{cpm} \times 100$, where total $\mathrm{cpm}$ indicates the sum of nonadherent cells, washes and adherent cells cpm. This value routinely exceeded $93 \%$ of total cell counts.

Specific binding to FN was calculated as the difference between total percentage adhesion and percentage adhesion not inhibited by anti-FN antibody (non-specific adhesion). Non-specific cell adhesion never exceeded $10 \%$.

\section{Inhibition assay}

For inhibition of the adhesion of Candida spp. to $\mathrm{FN}$, binding assays were performed following pretreatment of radiolabelled yeast cells for $30 \mathrm{~min}$ with a rabbit or a goat anti-FNr antiserum, anti- $\alpha 5$ SAM- 1 or P1D6 MAb, control antibody including normal goat IgG, rabbit IgG, and an anti-glucomannoprotein $\mathrm{MAb}$ or with different concentrations of GRGDSP and GRGESP peptides.

\section{Statistical analysis}

Statistical analysis by Student's $t$ test was performed by the STATPAC computerised program.

\section{Results}

Expression of a receptor antigenically related to $\alpha 5 \beta 1$ integrin by different Candida spp.

Adherence of Candida spp. to $\mathrm{FN}$ has been reported previously, ${ }^{30,31,35,42.43}$ but the molecular basis of this interaction has not yet been clearly defined. In an attempt to investigate the receptors involved in the specific adhesion of less pathogenic Candida spp. to $\mathrm{FN}$, the expression of the $\mathrm{FNr}$ prototype, $\alpha 5 \beta 1$ integrin, was evaluated on C. tropicalis, C. stellatoidea, C. glabrata and $C$. krusei by immunofluorescence and flow cytometric analysis with a panel of MAbs directed against the $\alpha 5$ (SAM-1, P1D6) or $\beta 1$ (A1A5, 4B4) subunit of human $\mathrm{FNr}$, or with a rabbit or goat polyclonal anti-FNr antibody purified from human placenta. As shown in fig. 1 and the table, C. tropicalis, C. glabrata and C. stellatoidea were positively stained by the anti- $\alpha 5$ SAM-1 MAb, with the greatest expression observed in $C$. tropicalis. In contrast, no immunoreactivity with the anti- $\alpha 5$ SAM- 1 MAb was observed in C. krusei. Marginal reactivity was detected with another anti- $\alpha 5 \mathrm{MAb}$, clone P1D6, in all Candida spp. analysed. Both rabbit and goat anti-FNr antisera positively stained all Candida spp. C. tropicalis and $C$. glabrata showed higher percentages of fluorescent cells and average MFI with rabbit and goat anti-FNr antiserum, respectively. As observed with the anti- $\alpha 5$ SAM-1 MAb, C. krusei reacted poorly with bone anti$\mathrm{FNr}$ antisera. No major reactivity was found with $\mathrm{MAb}$ directed against the $\beta 1$ integrin chain (A1A5, 4B4) in any Candida spp. tested.

These results indicate that the yeast forms of $C$. tropicalis, C. stellatoidea and C. glabrata-but not $C$. krusei - express an $\mathrm{FNr}$ antigenically related to $\alpha 5 \beta 1$ integrin as reported previously for C. albicans. ${ }^{43}$

\section{Candida spp. yeast cells specifically binding to $F N$}

The ability of the different Candida spp. to bind FN was evaluated by incubating ${ }^{3} \mathrm{H}$-glucose-labelled organisms on $\mathrm{FN}$-coated plates for $30 \mathrm{~min}$ at $37^{\circ} \mathrm{C}$ in the presence or absence of an anti-FN antibody or its $\mathrm{F}\left(\mathrm{ab}^{\prime}\right)_{2}$ fragment (data not shown). More than $90 \%$ of yeast cell adhesion to $\mathrm{FN}$ was specific as indicated by the ability of anti-FN antibody to completely inhibit binding to $\mathrm{FN}$, in a dose-dependent manner (fig. 2a). Higher levels of specific adhesion to $\mathrm{FN}$ were found for C. tropicalis and C. stellatoidea than for C. glabrata (fig. 2b). C. krusei bound to $\mathrm{FN}$ only marginally; adhesion was not increased by higher $\mathrm{FN}$ doses $(25-100 \mu \mathrm{g} / \mathrm{ml})$ or longer adhesion times $(30-60 \mathrm{~min})$ (data not shown). 


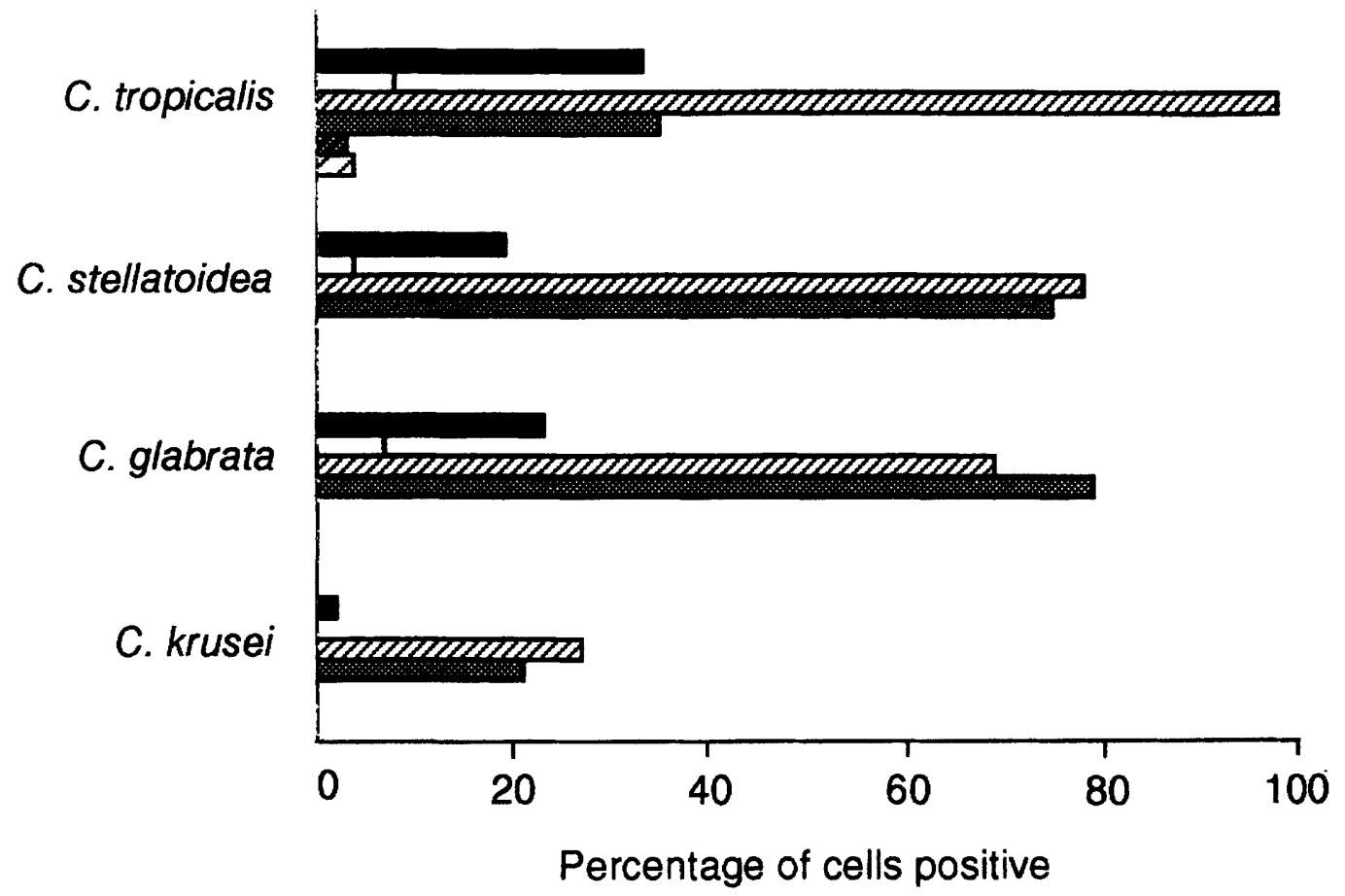

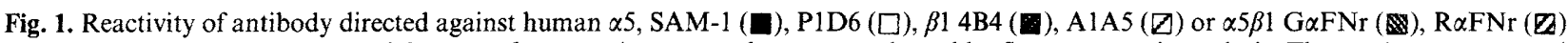
integrins with C. stellatoidea, C. glabrata, C. krusei and C. tropicalis yeasts evaluated by flow cytometric analysis. The results are presented as percentage of positive stained cells and represent one of four separate experiments.

Table. Expression of a $\alpha 5 \beta 1$ integrin-related fibronectin receptor on Candida spp. yeast cell

\begin{tabular}{lcccccc}
\hline & \multicolumn{6}{c}{ Mean fluorescence intensity (SD)* with antibody } \\
\cline { 2 - 7 } Candida spp. & SAM-1 & P1D6 & A1A5 & 4B4 & R $\alpha \mathrm{FNr}$ & $\mathrm{G} \alpha \mathrm{FNr}$ \\
\hline C. tropicalis & $6 \cdot 15(0.9)$ & $2.07(0.3)$ & $1.32(0.2)$ & $2.82(0.3)$ & $114.03(2.3)$ & $3.54(0.3)$ \\
C. stellatoidea & $3.06(0.7)$ & $1.39(0.2)$ & $1.25(0.1)$ & $1.51(0.3)$ & $7.35(0.7)$ & $8.14(1 \cdot 1)$ \\
C. glabrata & $3.73(0.8)$ & $1.38(0.1)$ & $0.92(0.1)$ & $0.97(0.1)$ & $5.89(0.7)$ & $9.42(1.0)$ \\
C. krusei & $1.25(0.3)$ & $0.79(0.1)$ & $0.66(0.2)$ & $0.98(0.1)$ & $1.83(0.1)$ & $1.86(0.3)$
\end{tabular}

Reactivity of anti- $\alpha 5$ (clones SAM-1 and P1D6), anti- $\beta 1$ (clones 4B4 and A1A5) MAb, goat $(\mathrm{G} \alpha \mathrm{FNr})$ and rabbit $(R \alpha \mathrm{FNr})$ anti-FNr antisera with $C$. tropicalis, C. stellatoidea, C. glabrata and $C$. kruse $i$ was evaluated by indirect immunofluorescence and flow cytometric analysis. *Mean fluorescence intensity (MFI) data are the means of four separate experiments and SD. MFI was calculated as the ratio between the MFI of the experimental group and MFI of the control (second-step reagent alone).

Adhesion of Candida spp. yeast cells to the 120-kDa proteolytic fragment of $F N$

The mechanisms involved in the adhesion of different $C$ andida spp. to $\mathrm{FN}$ were investigated further by testing the ability of $C$. tropicalis, $C$. stellatoidea, $C$. glabrata and C. krusei to specifically adhere to the 120 $\mathrm{kDa} F N$ proteolytic fragment which contains the RGDS cell binding site ${ }^{47}$ (fig. 3). C. tropicalis, $C$. glabrata and $C$. stellatoidea bound to $\mathrm{FN}$ as well as its $120-\mathrm{kDa}$ fragment, $C$. tropicalis being the most adhesive species. As observed with the entire FN molecule, $C$. krusei did not significantly bind to the 120-kDa FN fragment.

Inhibition of Candida spp. adhesion to $F N$ by $R G D$-containing peptides

Studies on mammalian cells have shown that $\alpha 5 \beta 1$ recognises the RGDS binding site in the central region of the FN molecule. ${ }^{41}$ To investigate the possible involvement of $\alpha 5 \beta 1$ in these interactions, the adhesion assay was performed in the presence of an RGDcontaining peptide (fig. 4). Pre-treatment of $C$. tropicalis, C. stellatoidea and C. glabrata yeast cells with different doses of GRGDSP peptide partially inhibited the adhesion to FN in a dose-dependent manner, with the highest inhibition found for $C$. tropicalis. No inhibition was observed in the presence of different doses of the control peptide GRGESP. These results indicate that adhesion of less pathogenic Candida spp. to FN is mediated by RGD-containing peptides.

Inhibition of Candida spp. adhesion to $F N$ by anti- $\alpha 5$, or anti-FNr antibodies

The possible involvement of $\alpha 5 \beta 1$ integrin in the adhesion of $C$. tropicalis, $C$. stellatoidea and $C$. 
a

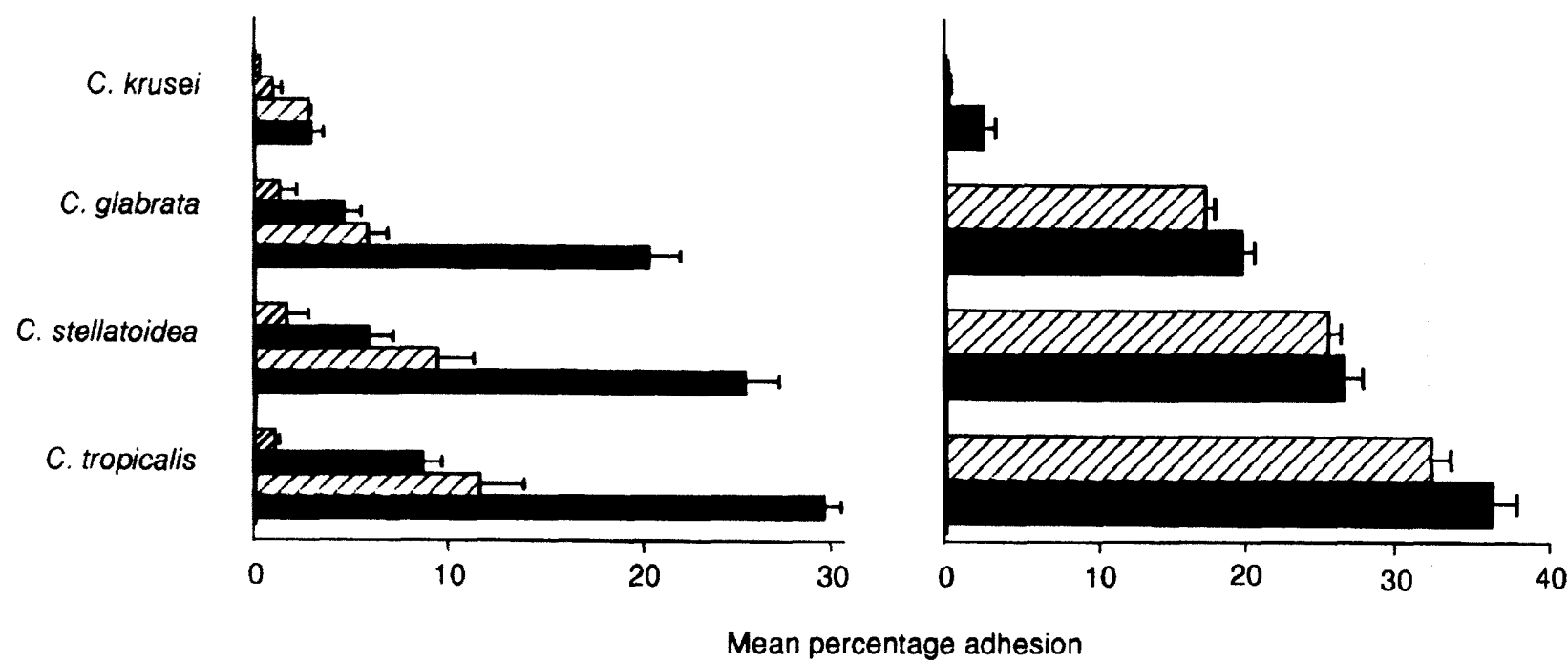

Fig. 2. C. tropicalis, C. stellatoidea, C. glabrata, but not $C$. krusei, specifically bind to FN. a, the adhesion of ${ }^{3} \mathrm{H}$-glucose-labelled $C a n d i d a$ spp. to FN $25 \mu \mathrm{g} / \mathrm{ml}$ was tested in the absence $(\square)$ or presence of different concentrations $(\square 1$ in $25 ; 1$ in $50 ; \square 1$ in 100$)$ of an anti-FN antiserum. The results are presented as the mean percentage adhesion and SD of three separate experiments. b, total ( $\square)$ and specific ( $\square)$ binding of Candida spp. to FN were evaluated in the presence of a saturating dose ( 1 in 25 ) of an anti-FN antiserum; the results are presented as the mean percentage adhesion and SD of five separate experiments.

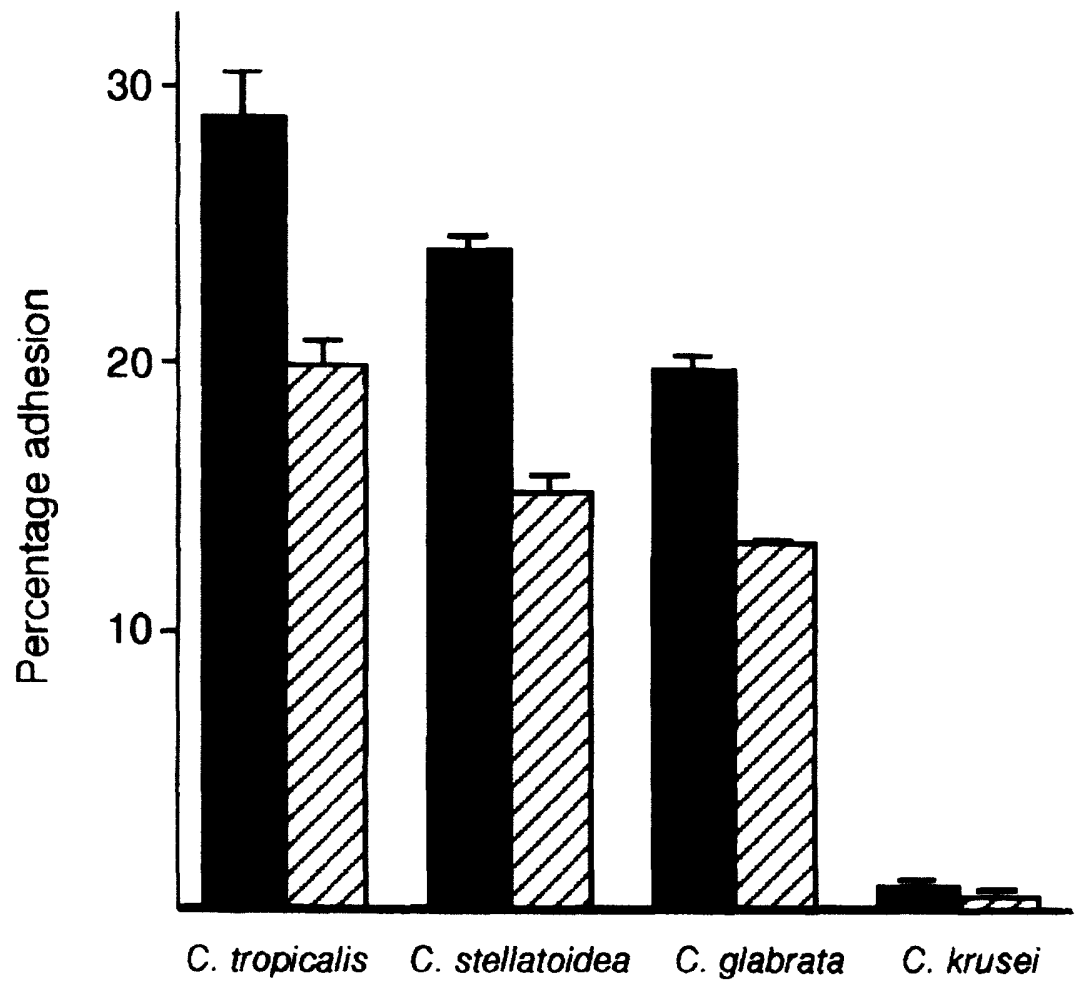

Fig. 3. Total ( $\square$ ) and specific ( $\square$ ) binding of Candida spp. yeast cells to the $120-\mathrm{kDa}$ FN proteolytic fragment. Specific adhesion of ${ }^{3} \mathrm{H}$-glucoselabelled Candida spp. yeast cells to the $120-\mathrm{kDa} F N$ fragment $(25 \mu \mathrm{g} / \mathrm{ml})$ was tested in the presence of a saturating dose (1 in 25$)$ of an antiFN antiserum. The results are presented as the mean percentage adhesion and SD of five separate experiments.

glabrata to FN was further analysed by testing the ability of antibodies directed against $\alpha 5$ or $\alpha 5 \beta 1$ heterodimer to inhibit yeast binding to FN (fig. 5). Pretreatment of yeast cells with different doses of both goat and rabbit anti-FNr antisera or with anti- $\alpha 5$ SAM-1 and P1D6 MAb strongly blocked the adhesion of Candida spp. to FN in a dose-dependent manner. No inhibition was found in the presence of an anti- mannan MAb or normal rabbit and goat IgG used as controls.

\section{Discussion}

Adherence of Candida spp. to ECM components, endothelial or epithelial cells represents an important 

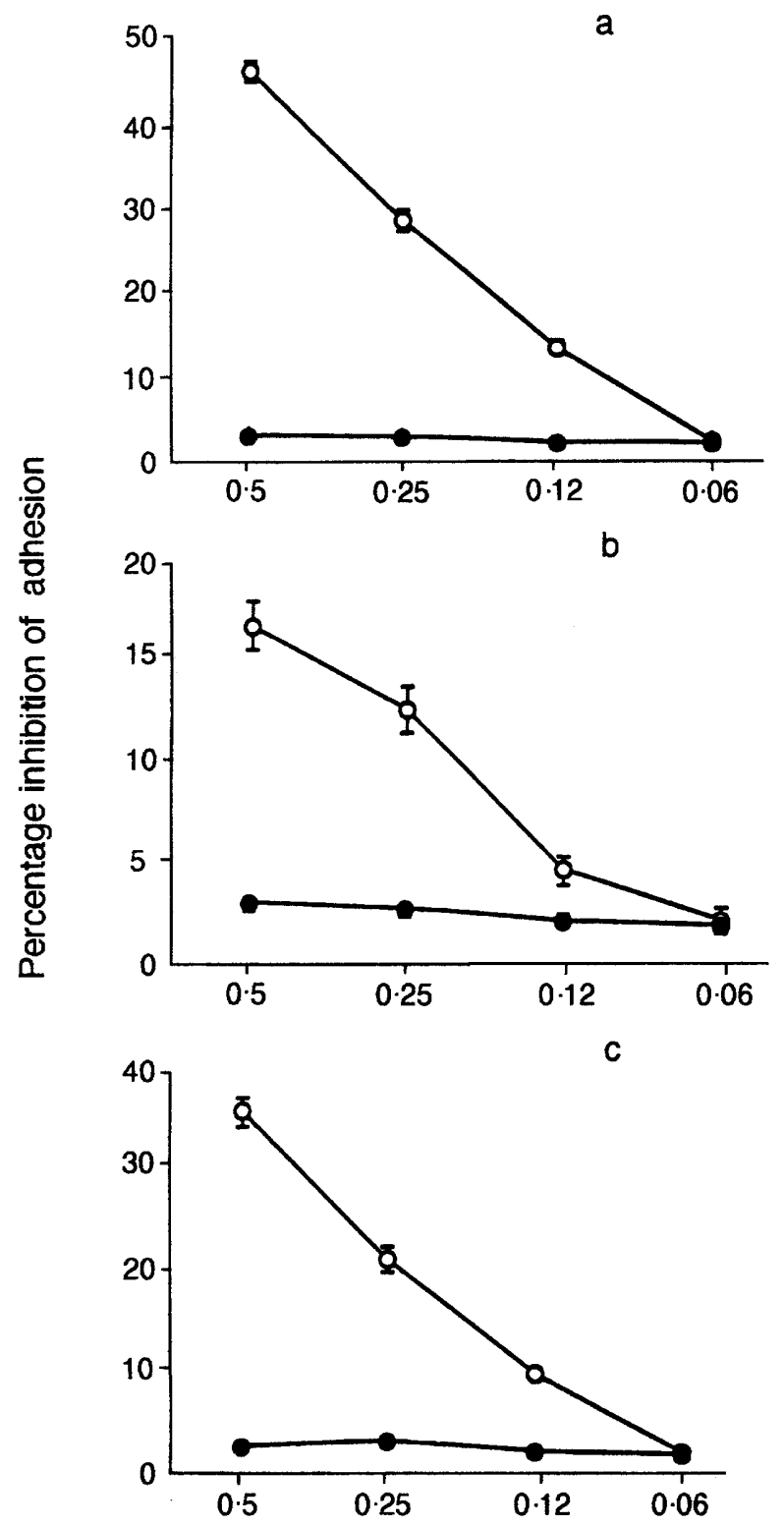

Peptide concentration $(\mathrm{mg} / \mathrm{ml})$

Fig. 4. Inhibition of (a) C. tropicalis, (b) C. stellatoidea and (c) C. glabrata adhesion to FN by an RGD-containing peptide. Adhesion of ${ }^{3} \mathrm{H}$-glucose-labelled Candida spp. yeast cells to FN $(25 \mu \mathrm{g} / \mathrm{ml})$ was tested in the presence of different concentrations of GRGDSP $(O)$ or GRGESP $(\odot)$ synthetic peptides. The results are the mean of quadruplicate determinations and are representative of three separate experiments. Specific cell adhesion calculated in the presence of a saturating dose (1 in 25) of an anti-FN antiserum was $90 \%$ of total adhesion.

step in the development of candidosis. Both yeast and germ-tube phases of $C$. albicans express a functional $\mathrm{FNr}$ antigenically related to $\alpha 5 \beta 1$, that is up-regulated during germ-tube transition and mediates adhesion to FN of both Candida phases. $^{43}$

The results of the present study indicate that yeast forms of less pathogenic Candida spp., including $C$. tropicalis, C. stellatoidea, C. glabrata, but not C. krusei, also express a surface receptor that shares antigenic homology with the $\alpha 5 \beta 1$ integrin and mediates adhesion to FN. Flow cytometric analysis indicates that certain antibodies directed against the human $\alpha 5$ integrin subunit or $\alpha 5 \beta 1$ heterodimer differentially bind to Candida spp. with $C$. tropicalis, C. stellatoidea and $C$.glabrata exhibiting high reactivity and $C$. kruse $i$ reacting only marginally. The expression of $\alpha 5 \beta 1$-like integrin directly correlated with the extent of Candida spp. adhesion to $\mathrm{FN} ; 20-30 \%$ of $C$. tropicalis, $C$. stellatoidea and $C$. glabrata yeasts specifically bound to $\mathrm{FN}$, whereas $C$. krusei failed to adhere to this ECM glycoprotein.

The $\alpha 5 \beta 1$-like receptor expressed by $C$. tropicalis, $C$. stellatoidea and $C$. glabrata is the primary mediator of adhesion to immobilised FN. The less pathogenic Candida spp. bound to the $120-\mathrm{kDa}$ proteolytic fragment of FN which contains the RGDS sequence recognised by $\alpha 5 \beta 1^{41}$ and their binding to the entire FN molecule was partially inhibited by GRGDSP, but not GRGESP peptides. More direct evidence that an $\alpha 5 \beta 1$-like integrin is involved in the interaction of Candida spp. with FN was obtained by the use of functional antibodies directed against $\alpha 5$ or $\alpha 5 \beta 1 \mathrm{FNr}$ that blocked specific adhesion to FN.

Expression of an $\mathrm{FNr}$ antigenically related to $\alpha 5 \beta 1$ on Candida spp. appears to be particularly significant for their interaction with host tissues such as epithelial or endothelial cells. Involvement of FN in the interaction of C. albicans or C. tropicalis with buccal and vaginal epithelial cells, epidermal keratinocytes or endothelium has been reported. ${ }^{4-55}$ Adhesion of $C$. albicans germ tubes to cultured human epidermal keratinocytes was partially inhibited by PepTite-2000, an RGD-containing synthetic peptide. ${ }^{50}$ Similarly, binding of $C$. tropicalis yeasts to epithelial cells was significantly inhibited by RGD peptides derived from FN but not from inactivated complement receptor type 3 (iC3b), while inverse results were obtained for C. albicans. ${ }^{49}$ Adhesion of $C$. albicans to endothelium is also RGD-dependent but probably involves more than one integrin receptor as suggested by the possible involvement of iC $3 b^{51}$

It is possible that $\alpha 5 \beta 1$-like receptors play a major role in the development of candida infection. A FNderived RGD-containing peptide affects the distribution and the fate of intravenously administered $C$. albicans yeast cells: ${ }^{56}$ after administration of RGDcontaining peptides, the heart, kidney and liver of treated animals had significantly fewer cfu of fungus and the number of renal abscesses was reduced.

Several animal and experimental models of infection have provided conclusive evidence for a hierarchy of relative virulence among the pathogenic Candida spp. These differences in virulence are closely paralleled by the varying abilities of Candida spp. to bind to epithelial and endothelial cells and complement components, as well as to ECM proteins. Thus, $C$. albicans attaches to exfoliated vaginal or buccal cells in much greater numbers than $C$. tropicalis (the next most adherent species), whereas $C$. krusei shows little or no adhesion. ${ }^{52}$ Similar species differences have been reported for adhesion to epidermal corneocytes, ${ }^{53}$ and vascular endothelium. ${ }^{54,55}$ In addition, mutant strains of C. albicans with reduced ability to adhere to human 


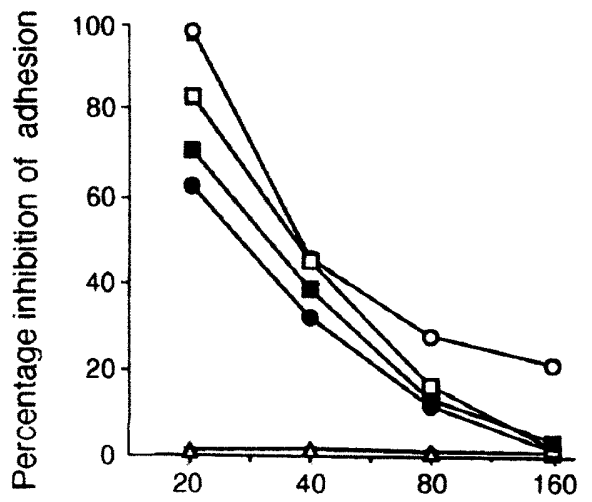

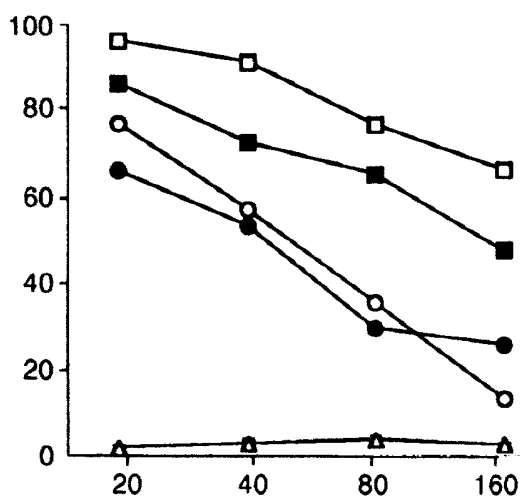

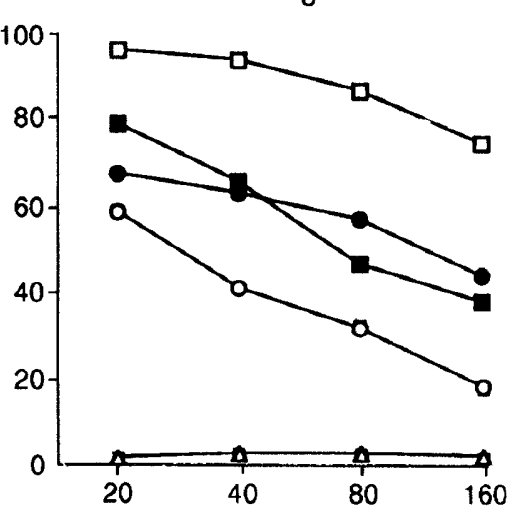

Antibody dilution factor

Fig. 5. Effect of anti- $x 5$ or anti- $\alpha 5 \beta 1$ antibody on (a) C. tropicalis, (b) $C$. stellatoidea and (c) C. glabrata adhesion to FN. ${ }^{3} \mathrm{H}$-glucose-labelled Candida spp. yeast cells were pre-treated for $30 \mathrm{~min}$ at $4^{\circ} \mathrm{C}$ with different dilutions of anti- $\alpha 5 \mathrm{SAM}-1$ (O) and P1D6 (O) MAb, goat anti-FNr antiserum ( $\square$ ), rabbit anti-FNr antiserum ( $)$ and normal goat or rabbit lg or a mouse MAb directed against a glucomannoprotein as control antibodies $(\triangle)$, and then tested for binding to $\mathrm{FN}(25 \mu \mathrm{g} / \mathrm{ml})$. The results are the mean of quadruplicate determinations and are representative of three separate experiments. Specific cell adhesion calculated in the presence of a saturating dose (1 in 25$)$ of an anti-FN antiserum was $90 \%$. None of the control antibodies inhibited adhesion, the results of normal rabbit Ig only are presented for simplicity.

vaginal epithelial cells in vitro were less virulent in animal models of vaginal candidosis. ${ }^{57}$ With regard to the ability of Candida spp. to bind complement components, $C$. albicans and $C$. stellatoidea, but not $C$. tropicalis or C. krusei, ${ }^{58}$ adhere to $\mathrm{iC} 3 \mathrm{~b}-$ and $\mathrm{C} 3 \mathrm{~d}$ coated sheep erythrocytes. Interestingly, adhesion to $\mathrm{iC} 3 \mathrm{~b}$ involves a receptor antigenically identical or similar to a mammalian integrin belonging to the $\beta 2$ subfamily, ${ }^{59.60}$ and its expression on Candida spp. directly correlates with Candida $\mathrm{iC} 3 \mathrm{~b}$ rosetting.

Adhesion of different Candida spp. to $\mathrm{FN}^{30}$ directly correlates with the ability to cause endocarditis in rabbits:36,38 moreover, Candida spp. with a high isolation frequency from endocarditis cases, such as $C$. tropicalis and $C$. albicans, show significantly higher binding to FN in vitro, whereas Candida spp. that do not adhere in vitro to FN (e.g., C. krusei) are rarely implicated in this disease.

These results show a correlation between the expression and function of $\alpha 5 \beta 1$ integrin-like receptor on Candida spp. and the hierarchy of relative virulence

\section{References}

1. Gold JWM. Opportunistic fungal infections in patients with neoplastic disease. Am J Med 1984: 76: 458-463.

2. Odds FC (ed). Disseminated candidosis ( $C$ andida septicemia) In: Candida and candidosis. 2nd edn. London. Bailliere Tindall. 1988: 206.

3. Komshian SV. Uwaydah AK. Sobel JD. Crane LR. Fungemia caused by Candida species and Torulopsis glabrata in the hospitalized patients: frequency, characteristics, and evaluation of factors influencing outcome. Rev Infect Dis 1989: 11:379-390.

4. Meunier F. Candidiasis. Eur J Clin Microbiol Infect Dis 1989;8: $438-447$

5. Banerjee SN. Emori TG, Culver DH et al. Secular trends in nosocomial primary bloodstream infections in the United States. 1980-1989. National Nosocomial Infections Surveillance System. Am J Med 1991; 91 Suppl 3B: 86S-89S.

6. Klein RS. Harris CA. Small CB, Moll B, Lesser M. Friedland GH. Oral candidasis in high-risk patients as the initial manifestation of the acquired immunodeficiency syndrome. N Engl J Med 1984; $311: 354-358$. among the pathogenic Candida spp. and suggest that the $\alpha 5 \beta 1$ analogue may be a significant virulence factor for these fungi. The highest infection capability showed by $C$. tropicalis directly correlated with the expression and function of $\alpha 5 \beta 1$ integrin-like receptor. Conversely, the poor infection capability exhibited by C. krusei may be attributable to the failure to express this receptor.

In conclusion, Candida-host cell interaction, is a multifactorial phenomenon involving different adhesion pathways. An understanding of the molecular basis of these adhesive interactions would enable the development of new therapeutic strategies; invasive infections may be prevented by specific blockade of fungal adherence receptors with adhesion molecule-based drugs.

We thank A. M. Bressan for expert technical assistance. We thank Drs M. Hemler, G. Tarone and A. Cassone for kindly providing some of the antibodies used in this study and $\mathrm{Dr} \mathrm{A}$. Gismondi for helpful discussion. This work was partially supported by MURST $40 \%$ and $60 \%$.

7. Armstrong D. Opportunistic infections in the acquired immune deficiency syndrome. Semin Oncol 1987; 142 Suppl 3: $40-47$.

8. Stellbrink HJ, Albrech H, Fenske S, Koperski K. Candida krusei sepsis in HIV infection. AIDS 1992; 6: 746-748.

9. Bach MC, Sahyoun A, Adler JL et al. High incidence of fungus infections in renal transplantation patients treated with antilymphocyte and conventional immunosuppression. Transpl Proc 1973; 5: 549-553.

10. Goodrich JM, Reed EC, Mori M et al. Clinical features and analysis of risk factors for invasive candidal infection after marrow transplantation. J Infect Dis 1991; 164: 731-740.

11. Wingard JR, Merz WG, Rinaldi MG, Johnson TR, Karp JE, Saral R. Increase in Candida krusei infection among patients with bone marrow transplantation and neutropenia treated prophylactically with fluconazole. N Engl J Med 1991; 325: 1274-1277.

12. Bodey GP. Candidiasis in cancer patients. Am J Med 1984; 77 (4D): 13-19.

13. Maksymuik AW, Thongprasert S, Hopfer R, Luna M, Fainstein V. Bodey GP. Systematic candidiasis in cancer patients. Am J Med 1984; 77 (4D): 20-27. 
14. Whimbey E, Kiehn TE, Brannon P, Blevins A, Armstrong D. Bacteremia and fungemia in patients with neoplastic disease. Am J Med 1987; 82: 723-730.

15. Sandin RL, Meier CS, Crowder ML, Greene JN. Concurrent isolation of Candida krusei and Candida tropicalis from multiple blood cultures in a patient with acute leukemia. Arch Pathol Lab Med 1993; 117: 521-523.

16. Hostetter MK. Adhesins and ligands involved in the interaction of Candida spp. with epithelial and endothelial surfaces. Clin Microbiol Rev 1994; 7: 29-42.

17. Dick JD, Merz WG, Saral R. Incidence of polyene-resistant yeasts recovered from clinical specimens. Antimicrob Agents Chemother 1980; 18 158-163.

18. Drutz DJ, Lehrer RI. Development of amphotericin B-resistant Candida tropicalis in a patient with defective leukocyte function. Am J Med Sci 1978; 276: 77-92.

19. Nobre G, Mendes E, Charrua MJ, Cruz O. Ketoconazole resistance in Torulopsis glabrata. Mycopathologia 1989; 107: 51-55.

20. Rubinstein E, Noriega ER, Simberkoff MS, Holzmann R, Rahal JJ. Fungal endocarditis: analysis of 24 cases and review of the literature. Medicine $1975 ; 54$ : 331-334.

21. Nolte $\mathrm{S}$. Clinical quiz. Obstructive fungal pyelonephritis Pediatr Nephrol 1992; 6: 119-120.

22. Edwards JE, Montgomerie JZ, Ishida K, Morrison JO, Guze LB. Experimental hematogenous endophthalmitis due to Candida: species variation in ocular pathogenicity. $J$ Infect Dis 1977; 135: 294-297.

23. McQuillen DP, Zingman BS, Meunier F, Levitz SM. Invasive infections due to Candida krusei: report of ten cases of fungemia that include three cases of endophthalmitis. Clin Infect Dis 1992;14 472-478.

24. Imahori SC, Papademetriou T, Ogliela DM. Torulopsis glabrata osteomyelitis. A case report. Clin Orthop 1987; 219 214-220.

25. Delaporte E, Piette F, Ehrsam E, Flipo RM, Fruit J, Bergoend $\mathrm{H}$. Chronic cutaneous candidiasis caused by Candida krusei. Ann Dermatol Venereol 1992; 119: 863-865.

26. Klotz SA. Fungal adherence to the vascular compartment: a critical step in the pathogenesis of disseminated candidiasis. Clin Infect Dis 1992; 14: 340-347.

27. Douglas LJ. Adhesion of Candida species to epithelial surfaces. Crit Rev Microbiol 1987; 15 : 27-43.

28. Calderone RA, Braun PC. Adherence and receptor relationships of Candida albicans. Microbiol Rev 1991; 55 $1-20$.

29. Tronchin G, Bouchara JP, Annaix V, Robert R, Senet JM. Fungal cell adhesion molecules in Candida albicans. Eur $J$ Epidemiol 1991; 7: 23-33.

30. Skerl KG, Calderone RA, Segal E, Sreevalson T, Scheld WM. In vitro binding of Candida albicans yeast cells to human fibronectin. Can J Microbiol 1984; 30: 221-227.

31. Klotz SA. The adherence of Candida yeasts to human and bovine vascular endothelium and subendothelial extracellular matrix. FEMS Microbiol Lett 1987; 48: 201-205.

32. Bouchara J-P, Tronchin G, Annaix V, Robert R, Senet J-M. Laminin receptors on Candida albicans germ tubes. Infect Immun 1990; 58: 48-54.

33. López-Ribot JL, Casanova M, Monteagudo C, Sepúlveda $\mathbf{P}$, Martinez JP. Evidence for the presence of a high-affinity laminin receptor-like molecule on the surface of Candida albicans yeast cells. Infect Immun 1994; 62: 742-746.

34. Klotz SA, Rutten MJ, Smith RL, Babcock SR, Cunningham MD. Adherence of Candida albicans to immobilized extracellular matrix proteins is mediated by calciumdependent surface glycoproteins. Microb Pathog 1993; 14: 133-147.

35. Jakab E, Paulsson M, Ascencio F, Ljungh A. Expression of vitronectin and fibronectin binding by Candida albicans yeast cells. APMIS 1993; 101: 187-193.

36. Scheld WM, Strunk RW, Balian G, Calderone RA. Microbial adhesion to fibronectin in vivo correlates with production of endocarditis in rabbits. Proc Soc Exp Biol Med 1985; 180: $474-482$

37. Segal E. Pathogenesis in human mycoses: role of adhesion to host surfaces. Microbiol Sci 1987; 4: 344-347.

38. Calderone RA, Scheld WM. Role of fibronectin in the patho- genesis of candidal infections. Rev Infect Dis 1987; 9 Suppl 4: $\mathrm{S} 400-\mathrm{S} 403$.

39. Ruoslahti E. Integrins. J Clin Invest $1991 ; 87$ : 1-5.

40. Hynes RO. Integrins: versatility, modulation, and signalling in cell adhesion. Cell 1992; 69: 11-25.

41. Takada $Y$, Huang C, Hemler ME. Fibronectin receptor structures in the VLA family of heterodimers. Nature 1987 ; 326: 607-609.

42. Klotz SA, Smith RL. A fibronectin receptor on Candida albicans mediates adherence of the fungus to extracellular matrix. $J$ Infect Dis 1991; 163: 604-610.

43. Santoni G, Gismondi A, Jin Hong L et al. Candida albicans expresses a fibronectin receptor antigenically related to

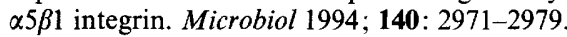

44. Conforti G, Zanetti A, Colella S et al. Interaction of fibronectin with cultured human endothelial cells: characterization of the specific receptor. Blood 1989; 73: 1576-1585.

45. Torosantucci A, Boccanera M, Casalinuovo I, Pellegrini G, Cassone A. Differences in the antigenic expression of immunomodulatory mannoprotein constituents on yeast and mycelial forms of Candida albicans. $J$ Gen Microbiol 1990; 136: 1421-1428.

46. Djeu JY, Parapanissios A, Halkias D, Friedman H. A rapid $\left[{ }^{3} \mathrm{H}\right]$-glucose incorporation assay for determination of lymphoid cell-mediated inhibition of Candida albicans growth. J Immunol Methods 1986; 92: 73-77.

47. Pierschbacher MD, Hayman EG, Ruoslahti E. Location of cellattachment site in fibronectin with monoclonal antibodies and proteolytic fragments of the molecule. Cell 1981; 26: 259-267.

48. Kalo A, Segal E, Sahar E, Dayan D. Interaction of Candida albicans with mucosal surfaces: involvement of fibronectin in adherence. $J$ Infect Dis 1988; 157: 1253-1256.

49. Bendel CM, Hostetter MK. Distinct mechanisms of epithelial adhesion for Candida albicans and Candida tropicalis. Identification of the participating ligands and development of inhibitory peptides. J Clin Invest 1993; 92: 1840-1849.

50. Ollert MK, Söhnchen R, Korting HC, Ollert U, Braütigam S, Braütigam W. Mechanisms of adherence of Candida albicans to cultured human epidermal keratinocytes. Infect Immun 1993; 61 : $4560-4568$.

51. Gustafson KS, Vercellotti GM, Bendel CM, Hostetter MK. Molecular mimicry in Candida albicans. Role of an integrin analogue in adhesion of the yeast to human endothelium. $J$ Clin Invest $1991 ; 87$ : 1896-1902.

52. King RD, Lee JC, Morris AL. Adherence of Candida albicans and other Candida species to mucosal epithelial cells. Infect Immun 1980; 27: 667-674.

53. Ray TL, Digre KB, Payne CD. Adherence of Candida species to human epidermal corneocytes and buccal mucosal cells: correlation with cutaneous pathogenicity. $J$ Invest Dermatol 1984; 83: 37-41.

54. Klotz SA, Drutz DJ, Harrison JL, Huppert H. Adherence and penetration of vascular endothelium by Candida yeasts. Infect Immun 1983; 42: 374-384.

55. Rotrosen D, Edwards JE, Gibson TR, Moore JC, Cohen AH, Green I. Adherence of Candida to cultured vascular endothelial cells: mechanisms of attachment and endothelial cell penetration. J Infect Dis $1985 ; 152$ : 1264-1274.

56. Klotz SA, Smith RL, Stewart BW. Effect of an arginine-glycineaspartic acid-containing peptide on hematogenous candidal infections in rabbits. Antimicrob Agents Chemother 1992; 36: 132-136.

57. Lehrer N, Segal E, Cihlar R, Calderone RA. Pathogenesis of vaginal candidiasis: studies with a mutant which has reduced ability to adhere in vitro. $J$ Med Vet Mycol 1986; 24: $127-132$.

58. Heidenreich F, Dierich MP. Candida albicans and Candida stellatoidea, in contrast to other Candida species, bind $\mathrm{iC} 3 \mathrm{~b}$ and C3d but not C3b. Infect Immun 1985; 50: 598-600.

59. Edwards JE, Gaither TA, O'Shea JJ et al. Expression of specific binding sites on Candida with functional and antigenic characteristics of human complement receptors. $J$ Immunol 1986; 137 : 3577-3583.

60. Hostetter MK, Lorenz JS, Preus L, Kendrick KE. The iC3b receptor on Candida albicans: Subcellular localization and modulation of receptor expression by glucose. $J$ Infect Dis $1990 ; 161: 761-768$. 